\title{
Üniversite Yaşamında Sosyal Uyumun Yordayıcısı Olarak Spora Yönelik Tutum
}

\author{
Serkan Kurtipek ${ }^{1}$ (D) , Nuri Berk Güngör² (D) , Baki Yılmaz³ (D) , Fatih Yenel ${ }^{1}$ \\ ${ }^{1}$ Gazi Üniversitesi, Spor Bilimleri Fakültesi, ANKARA \\ ${ }^{2}$ Karamanoğlu Mehmetbey Üniversitesi, Spor Bilimleri Fakültesi, KARAMAN \\ ${ }^{3}$ Ankara Yıldırım Beyazıt Üniversitesi, Spor Bilimleri Fakültesi, ANKARA
}

Araştırma Makalesi

DOI: $10.53434 / g b e s b d .947778$

Öz

Bu çalıșmanın amacı, spor bilimleri fakültesi öğrencilerinin spora yönelik tutumlarının üniversite yaşamında sosyal uyumları üzerine etkisini belirlemektir. Araştırmanın çalışma grubunu, 2020-2021 eğitim öğretim yllında bir kamu üniversitesinin spor bilimleri fakültesinde öğrenim görmekte olan 203 ögrrenci oluşturmaktadır. Araștırmada veri toplama aracı olarak kişisel bilgi formunun yanı sıra, Şentürk (2012) tarafindan geliştirilen Spora Yönelik Tutum Ölçeği ve Aslan (2015) tarafindan geliştirilen Üniversite Yaşamına Uyum Ölçeği kullanılmıştır. Araştırma sonuçları dikkate alındığında; katılımcıların spora yönelik tutumları ve yaşam uyumu düzeyinin ortalamanın üzerinde olduğu ifade edilebilir. Bununla beraber; spora ilgi duyma ve aktif spor yaşamı ile üniversite yaşamına uyum ilişsisinde anlamlı bir etki olduğu belirlenmiştir. Son olarak; üniversite yaşamına uyumun \%.05'inin yordayıcı değişkenler olan spora ilgi duyma, sporla yaşama ve aktif spor yaşamı tarafından açılklandığı belirtilebilir.

Anahtar sözcükler: Yaşam uyumu, Spor, Üniversite 


\title{
Attitude towards Sports as a Predictor of Social Adaptation in University Life
}

\begin{abstract}
The aim of this study is to determine the effect of sports science faculty students' attitudes towards sports on their social adaptation in university life. The study group of the research consists of 203 students studying at the sports sciences faculty of a public university in the 2020-2021 academic year. In addition to the personal information form, the Attitude towards Sports Scale developed by Şentürk (2012) and the Scale of Adaptation to University Life developed by Aslan (2015) were used as data collection tools in the research. Considering the research results; It can be stated that the attitudes of the participants towards sports and the level of life adjustment are above the average. However; It has been determined that there is a significant effect on the relationship between interest in sports and active sports life and adaptation to university life. In addition; It can be stated that .05\% of adaptation to university life is explained by the predictive variables of interest in sports, living with sports and active sports life.
\end{abstract}

Keywords: Life harmony, Sport, University

\section{Giriş}

Tutum, insan davranışını anlamak için önemli bir kavramdır. İnançları ve duyguları içeren karmaşık bir zihinsel durum olarak tanımlanır (Latchanna ve Dagnew, 2009). İnsanlar devamlı olarak çevrelerini algılamakta, karşılaştığı kişiler yaşadığı olaylar karşısında bilgiler toplamakta ve toplamış olduğu bu bilgileri sentezleyerek düşünce inanç ve değerler oluşturmaktadır. İnsanlarda oluşan bu düşünce, inanç ve değerler onların diğer canlı ve cansız varlıklara farklı bir şekilde davranmalarına neden olur (Çöllü ve Öztürk, 2006).

Günlük hayatımızda çok sık kullandığımız tutum kavramı birçok davranışı ve davranış değişikliklerini açıklamamıza yardımcı olur. Kuşkusuz bu davranış değişiklerinin meydana getirdiği durumlardan birisi de spordur. Sporla iç içe bir toplum oluşturmak için yapılmış tüm çalışmaların özünü dikkate alarak, kişinin spor yapmaya yatkınlığı, spora karşı bakış açısı, spor ile ilgili alışkanlıkları, spor yoluyla kişinin kendini nasıl eğitebildiği gibi önemli konuların, özetle bireylerin spora yönelik tutumlarının irdelenmesi gerekmektedir (Şentürk, 2012).

Anayasanın 58. ve 59. maddelerinde belirtilen devletin, gençleri alkol bağımlılığından, uyuşturucu maddelerden, suçlardan, kumar ve buna benzer kötü alışkanlıklardan ve bilgisizlikten koruyabilmesi yine sporun kitlelere yayılabilmesi için spora yönelik olumlu tutum geliştirmek elzem bir durum olarak karşımıza çıkmaktadır. Bu açıdan ilk olarak ergenlik çağındaki bireyleri olumsuz alışkanlıklardan korumak ve aktif olarak fiziksel, zihinsel ve sosyal açıdan dinç tutabilmek için genç yaşlardan başlayarak yapılandırılan spora yönelik pozitif bir bakış açısı önemli görülmektedir (Göksel, Caz, Yazıcı ve İkizler, 2017).

Çağımızda spor, içinde bulunduğumuz toplumsal yaşamdan farklı düşünülmemektedir. Sporu sosyolojik ve felsefi olarak inceleyen bilimsel çalışmalar (Ayyıldız-Durhan, 2020, Ayyılıdız-Durhan ve Karaküçük, 2020; Bindesen ve Bindesen, 
2020; Cengiz ve Taşmektepliğil, 2016; Halıcı, Parasız ve Yetim, 2020; Yarayan, Yıldız ve Gülşen 2018; Yarayan, Yıldız, Gülşen ve İlhan, 2020; Yetim, 2000), sporun toplumsal yapının bir yansıması olduğunu göstermektedir. Toplumları ilgilendiren bir diğer konu ise sosyal uyumdur.

Uyum, bireyin kendisinden, başkalarından ya da çevresinden gelen talepler karşısında verdiği reaksiyondur (Napoli, Kilbride ve Tebs, 1996). Sosyal uyum ise bir toplumda itimat, katılım, yardım ve bağlanma duygularını içine alan bir dizi tutum ve kuralların yanı sıra davranışsal tezahürlerini de kapsayan bir kavramdır (Chan, Zhang ve Wang, 2006). İnsanların hayatlarındaki her türlü değişim, uyum sürecini de birlikte getirmektedir. $\mathrm{Bu}$ değişimde çevre, aile, arkadaş grubu, eğitim ve spor büyük rol oynamaktadır.

Üniversite hayatında bir gruba üye olmabilme, kariyer sahibi olabilme ve geleceğe yön verebilme hedefleri ile yeni bir eğitim kurumuna, bir șehire ve yabancı bir çevreye uyum sağlayabilme uğraşları çoğu gençte bazı uyum sorunlarının meydana gelmesine sebep olmaktadır (Aktaş, 1997). Bu problem karşısında üniversite öğrencilerinin özellikle spora yönelik tutumlarının üniversite hayatındaki sosyal gelişimine etkilerinin olabileceği, dolayısıyla öğrencilerin ilgili dönemde ve akademik yaşamdan sonraki süreçte sosyal uyumu daha kolay sağlayabileceği düşüncesi bu araştırmanın çıkış noktasını oluşturmaktadır. Buradan hareketle, bu çalışma spor bilimleri fakültesi öğrencilerinin spora yönelik tutumlarının üniversite yaşamında sosyal uyumları üzerine etkisinin belirlenmesi amacıyla yürütülmüştür.

\section{Yöntem}

\section{Araştırma Modeli}

Spor bilimleri fakültesinde öğrenim görmekte olan bireylerin spora yönelik tutumlarının üniversite yaşamında sosyal uyumları üzerine etkilerinin incelendiği bu araştırmada ilişkisel tarama modeli kullanılmıştır. Karasar (2013) bu modeli, "iki ve daha çok sayıda değişken arasında birlikte değişim varlığını ve/veya derecesini belirlemeyi amaçlayan araştırma modelleridir" ifadesi ile açıklamıştır.

Araştırmanın etik kurul onayı, Gazi Üniversitesinin Etik Komisyonu'ndan 20.04.2021 tarih ve E-77082166-604.01.02-97963 sayılı karar ile alınmıştır.

\section{Çalışma Grubu}

Araştırmanın çalışma grubunu, 2020-2021 eğitim öğretim yılında bir kamu üniversitesinin spor bilimleri fakültesinde öğrenim görmekte olan 91'i (\%45.82) kadın, 110’u (\%54.12) erkek katılımcı oluşturmaktadır. Araștırmanın örneklem seçiminde, amaçlı örneklem yöntemlerinden ölçüt örnekleme ile kolay ulaşılabilir örnekleme metodu uygulanmıştır. Araştırmada yer alan katılımcıların yaş ortalaması $20.8 \pm 2.13$ 'dür. 


\section{Veri Toplama Araçları}

Araştırmada, Spora Yönelik Tutum ve Üniversite Yaşamına Uyum Ölçekleri ile kişisel bilgi formu kullanılmıştır.

\section{Spora Yönelik Tutum Ölçeği}

Ölçek, Şentürk (2012) tarafından literatüre kazandırılmıştır. Toplamda 25 madde ve 3 alt boyuttan oluşan ölçek 5'li likert bir yapıdadır. Alt boyutları; spora ilgi duyma, sporla yaşama ve aktif spor yapma olarak isimlendirilmiştir. Ölçekten alınan toplam puanın artması spora yönelik tutumunda artışı anlamına gelmektedir. Veri setinden elde edilen doğrulayıcı faktör analizi sonuçları, Spora Yönelik Tutum Ölçeğinin 3 boyutlu faktör yapısını doğrulamaktadır $\left(\mathrm{x}^{2} / \mathrm{sd}=3.35\right.$, RMSEA $=.07$, $\mathrm{PGFI}=.73$, PNFI= .74, GFI= .89, AGFI= .88, CFI= .91). Ölçeğin tamamı için elde edilen iç tutarlık katsayısı .91; alt boyutlara ait iç tutarlık katsayısı ise sırasıyla $.88, .73$ ve .67 olarak elde edilmiştir.

\section{Üniversite Yaşamına Uyum Ölçeği}

Üniversite Yaşamına Uyum Ölçeği, Aslan (2015) tarafından geliştirilerek geçerlik ve güvenirlik çalışması yapılmıştır. Ölçeğin orijinal formu; kişisel uyum, sosyal uyum ve akademik uyum olarak 3 alt boyuttan oluşmaktadır. Ölçekte yer alan her bir alt boyut ayrı ayrı da kullanılabilmektedir. Bu nedenle araștırmada sosyal uyum alt boyutu ayrı olarak kullanılmıștır. Sosyal uyum alt boyutu 20 maddeden ve 5'li likert bir yapıdan oluşmaktadır. Ölçekten alınan puan yükseldikçe sosyal uyum düzeyi de artmaktadır. Puan sınıflandırması ise şu şekildedir; 0-70 puan çok az uyum, 71-91 puan az uyum ve 72-100 puan ise yüksek uyum anlamına gelmektedir. Bununla beraber, Üniversite Yaşamına Uyum Ölçeğinin Sosyal Uyum alt boyutunun tek faktörlü yapısı doğrulanmıştır $\left(\mathrm{x}^{2} / \mathrm{sd}=2.20\right.$, RMSEA= .06, PGFI= $.93, \mathrm{PNFI}=.72, \mathrm{GFI}=.88, \mathrm{AGFI}=.85, \mathrm{CFI}=.97)$. Araştırmanın veri setinden elde edilen iç tutarlık katsayısı 83 olarak belirlenmiștir.

\section{Verilerin Analizi}

Veri setinin analizi işleminde öncelikle uç değerlere sahip olan 8 araştırma formu çıkarılmıştır. Sonrasında, veri setinin normal dağılıp dağılmadığının belirlenebilmesi amacıyla Shapiro-Wilk testi anlamlılık sonucu incelenerek çarpıklık ve basıklık değerleri incelenmiştir. Araştırmada yer alan ölçme araçları için ilgili değerler -1.5 ile +1.5 arasındadır (SYTÖ: -.92, .89; SUÖ: -.41, -.05). Bu sonuç verilerin normal dağılım gösterdiğini ifade etmektedir (Tabachnick ve Fidell, 2013).

Ölçeklerin faktör yapılarının testi amacıyla Doğrulayıcı Faktör Analizi gerçekleştirilmiştir. Araștırmada yer alan değişkenler arasındaki ilişkinin belirlenebilmesi amacıyla Pearson Momentler Çarpım Korelasyon Katsayısı ( $r$ ) kullanılmıştır. Spora yönelik tutum alt boyutları ve üniversite yaşamına uyum arasında çoklu doğrusal regresyon analizi uygulanmıştır. Ayrıca, ölçeklerden alınan puan ortalamalarını belirleyebilmek amacıyla betimsel istatistiklerden yararlanılmıştır. Araştırmada kullanılan analizler AMOS 22, SPSS 22 Paket Programları ve Excel veri tabanı aracılığı ile gerçekleştirilmiştir. 


\section{Bulgular}

$\mathrm{Bu}$ bölümde verilerin analizi sonucunda elde edilen bulgular sunulmuștur.

Tablo 1. Katılımclların spora yönelik tutum ve üniversite yaşamına sosyal uyum ölçeklerinden aldıkları ortalama puanların dağılımı

\begin{tabular}{lccccc}
\hline ölçekler & $\mathbf{N}$ & Min. & Maks. & $\overline{\mathbf{x}}$ & Ss \\
\hline Spora İlgi Duyma & 203 & 1.00 & 5.00 & 3.68 & .78 \\
Sporla Yaşama & 203 & 1.29 & 5.00 & 3.62 & .73 \\
Aktif Spor Yaşamı & 203 & 1.00 & 5.00 & 3.47 & .82 \\
\hline Spora Yönelik Tutum & 203 & 1.28 & 4.92 & 3.61 & .70 \\
\hline Üniversite Yaşamına Sosyal Uyum & 203 & 2.40 & 4.55 & 3.70 & .43 \\
\hline
\end{tabular}

Katılımcıların Spora Yönelik Tutum Ölçeğinden aldıkları ortalama puan $\bar{x}=3.61$ iken, Üniversite Yaşamına Sosyal Uyum alt boyutunda ise $\bar{x}=3.70$ olarak tespit edilmiştir. Bununla beraber, Spora Yönelik Tutum Ölçeğinin alt boyutlarından elde edilen ortalama puanlar "spora ilgi duyma" için $\overline{\mathrm{x}}=3.68$, "sporla yaşama" için $\overline{\mathrm{x}}=3.62$ ve "aktif spor yaşamı" için $\overline{\mathrm{x}}=3.47$ olarak belirlenmiștir.

Tablo 2. Değişkenler arası ilişkinin Pearson momentler çarpımı korelasyonu

\begin{tabular}{llllll}
\hline & Si & SY & AS & SYT & ÜYSU \\
\hline Spora İlgi Duyma (Si) & 1 & & & & \\
\hline Sporla Yaşama (SY) & $.75^{* *}$ & 1 & & & \\
\hline Aktif Spor Yaşamı (AS) & $.68^{* *}$ & $.65^{* *}$ & 1 & & \\
\hline Spora Yönelik Tutum (SYT) & $.94^{* *}$ & $.88^{* *}$ & $.83^{* *}$ & 1 & \\
\hline Üniversite Yaşamına Sosyal Uyum (ÜYSU) & $.16^{*}$ & $.12^{*}$ & $.015^{*}$ & $.13^{*}$ & 1 \\
\hline$* * p<01^{*}$ p $<05$ & & & & &
\end{tabular}

${ }^{* *} \mathrm{p}<.01,{ }^{*} \mathrm{p}<.05$

Tablo 2 incelendiğinde; SYT ile ÜYSU arasında pozitif yönlü ve düșük düzeyde bir ilişki tespit edilmiştir. Buna ek olarak; Sİ, SY ve AS ile ÜYSU arasında ise yine pozitif yönlü ve düşük düzeyde bir ilişkinin olduğu görülmektedir.

Tablo 3. Sosyal uyumun yordanmasına ilişki çoklu regresyon analizi sonuçları

\begin{tabular}{|c|c|c|c|c|c|c|}
\hline \multicolumn{2}{|c|}{ Değişkenler } & $\begin{array}{c}\text { Standardize } \\
\beta\end{array}$ & $\begin{array}{c}\text { Standart } \\
\text { Hata }\end{array}$ & $\begin{array}{c}\text { Kritik } \\
\text { Oran }\end{array}$ & $\mathbf{p}$ & $\mathbf{R}^{2}$ \\
\hline \multirow{3}{*}{$\begin{array}{l}\text { Spora İ. Duyma } \\
\text { Sporla Yaşama } \\
\text { Aktif S. Yaşamı }\end{array}$} & \multirow{3}{*}{$\begin{array}{l}\text { Üniversite } \\
\text { Yaşamına } \\
\text { Sosyal Uyum }\end{array}$} & .14 & .06 & 2.28 & .02 & \multirow{3}{*}{.05} \\
\hline & & .03 & .07 & .53 & .60 & \\
\hline & & -.10 & .05 & -2.01 & .04 & \\
\hline
\end{tabular}

Tablo 3'e göre, spora ilgi duyma ve aktif spor yaşamı ile üniversite yaşamına sosyal uyum ilişkisinde anlamlı bir etki olduğu görülmektedir $\left(\beta_{1}=.14 ; \mathrm{p}<.05 ; \beta_{3}=-.10 ; \mathrm{p}<.05\right)$. Sporla yaşama değişkeninin ise, üniversite yaşamına sosyal uyum üzerinde anlamlı bir etkisinin olmadığı belirlenmiștir, $\left(\beta_{2}=.03\right.$; p>.05). Ayrıca, üniversite yaşamına sosyal uyumun \%.05'inin yordayıcı değişkenler olan spora ilgi duyma, sporla yaşama ve aktif spor yaşamı tarafından açıklandığı belirtilebilir. 


\section{Tartışma ve Sonuç}

Spor bilimleri fakültesinde öğrenim görmekte olan bireylerin spora yönelik tutumlarının üniversite yaşamında sosyal uyumları üzerine etkilerinin incelendiği araştırma kapsamında, katılımcıların Spora Yönelik Tutum Ölçeğinden yüksek düzeyde puan ortalaması $(\overline{\mathrm{x}}=3.61)$ elde ettikleri ifade edilebilir. Aynı zamanda spor bilimleri fakültesi öğrencilerinin, Spora Yönelik Tutum Ölçeği alt boyutları olan spora ilgi duyma ( $\bar{x}=3.68$ ), sporla yaşama $(\overline{\mathrm{x}}=3.62)$ ve aktif spor yaşamı alt boyutlarında $(\overline{\mathrm{x}}=3.47)$ da ortalamaların üzerinde tutum düzeyi sergiledikleri saptanmıștır. Spor bilimleri fakültesi öğrencilerine yönelik yapılan araştırma bulgularına paralel olarak yapılan çalışmalar, öğrencilerin spora yönelik tutum düzeylerinin genel olarak orta ve yüksek seviyede olduğu yönündedir (Atalı, Uzuner, Çolak ve Bayazıt, 2018; Birsin-Yıldız, Arı ve Yılmaz, 2017; Caz, Bıçakçı ve Nakipoğlu- Firuzan, 2019; Çakır ve Özdurak-Sıngın, 2019, Güngör ve Çelik, 2020; Nacar, Gacar ve Tutar, 2019; Şimşek ve Karahüseyinoğlu, 2020; Türkmen, Abdurahimoğlu, Varol ve Gökdağ, 2016; Varol, Varol ve Türkmen, 2017; Zaman, Mian ve Butt, 2018).

Antrenörlük eğitimi, beslenme, fizyoterapi ve rehabilitasyon ve diyetetik bölümlerinde öğrenim gören öğrencilerin spora yönelik tutum düzeylerinin belirlendiği bir diğer araştırma bulguları, sporla yaşama alt boyutunda fizyoterapi ve rehabilitasyon bölümü öğrencilerinin lehine anlamlı farkllılılar ortaya koymuştur (Göksel ve diğ., 2017). Farklı bir araştırmada elde edilen bulgular, benzer şekilde örneklem grubu içinde çoğunluğu spora aktif katılmayan öğrencilerin spora yönelik tutumlarının yüksek olduğu yönündedir (Şimşek ve Karahüseyinoğlu, 2020). Diş hekimliği fakültesi öğrencileri üzerinde yapılan bir diğer araştırmada ise bulgular, spor etkinliği dersine düzenli olarak katılım gösteren öğrencilerin \%86,5'inin spor etkinliği dersinin kendilerinde olumlu bir katkısı olduğu biçimindedir (Kalfa, 2019). Literatürden elde edilen bilgiler doğrultusunda spor etkinlikleriyle iç içe olmanın spora yönelik tutumu geliştirdiği söylenebilir.

Spor yapmanın spora yönelik tutumu, psikososyal, fiziksel ve zihinsel özellikleri olumlu etkilediği saptanan araştırma bulguları (Sarı ve Taylan, 2020), spor bilimleri fakültesi öğrencileri açısından ortaya çıkan olumlu tutum düzeyi bulgularını destekler niteliktedir. Spor bilimleri fakültesi öğrencilerinin aktif olarak spor faaliyetlerine katılımına benzer şekilde, katılımcıların okullararası müsabakalarda görev alma durumları ve spora yönelik tutumlarının karşılaştırılmasında; sporla yaşama ve aktif spor yapma değişkenleriyle spora yönelik tutum arasında anlamlı farklılıklara rastlanmazken; spora ilgi duyma alt boyutunda bu müsabakalarda görev alan öğrenciler lehine anlamlı farklılığa rastlanmıştır (Mızrak, Biricik ve Belli, 2017). Bununla beraber, alanyazında yer alan araştırmalar spora yönelik tutumun pek çok farklı değişkenle (Atalı ve diğ., 2018; BirsinYıldız, Arı ve Yılmaz, 2017; Başsonuş, 2020; Gökdağ, 2018; Tukel, 2018; Varol, 2017; Varol, Varol ve Türkmen, 2017; Yanık ve Çamlıyer, 2015; Yavuz ve Yücel, 2019; Yıldırım, AraçIlgar ve Uslu, 2018) ve farklı ölçüm araçlarıyla (Belli, Bedir ve Turan, 2019; Caz, Bıçakçı ve Nakipoğlu-Firuzan, 2019; Çakır ve Özdurak-Sıngın, 2019; Çoban, 2019; Demir, 2020) incelendiğini göstermektedir. 
Spor bilimleri fakültesi öğrencilerinin sosyal uyum düzeyinin ortalamanın üzerinde olduğu ( $\bar{x}=3.70)$ belirlenmiştir. Araştırma bulgularına paralel olarak farklı bölümlerde öğrenim gören öğrencilerin üniversiteye uyum düzeylerinin yüksek olduğu (Karahan, Sakdoğan, Özkamalı ve Dicle, 2005a; Yılmaz ve Zembat, 2019) saptanmıștır. Üniversite öğrencilerinin uyum düzeylerinin incelenmesine yönelik yapılan bir araştırmada öğrencilerin son sınıftaki kişisel, sosyal ve genel uyum seviyelerinin birinci sınıftaki uyum seviyelerinden anlamlı derecede daha iyi olduğu belirlenmiştir (Aktaş, 1997). Öğrencilerin okulda geçirdikleri süre ve sosyal, sportif etkinlikler vasıtasıyla sosyal uyum düzeylerinin artış gösterdiğini söylemek mümkündür. Aktif olarak sosyo-kültürel etkinliklere katılan öğrencilerin akademik, sosyal, duygusal ve kişisel ilişkileri ile üniversite ortamına uyum düzeylerinin, katılmayan öğrencilere göre daha yüksek olduğu araştırmalar ile desteklenmektedir (Karahan, Sakdoğan, Özkamalı ve Dicle, 2005b). Bu araştırmaların aksine Temel Eğitim Bölümü birinci sınıfta öğrenim gören öğretmen adaylarının üniversite yaşamına uyum süreçlerinin incelendiği araştırma kapsamında, öğrencilerin üniversite yaşamına uyum düzeylerinin çok yüksek olmadığı belirlenmiştir (Esen-Aygün ve Şahin Taşkın, 2019). Ortaya çıkan bulgunun öğrencilerin 1. Sınıfta olmasından kaynaklandığı düşünülmektedir. Üniversitede geçirilen süre ve edinilen sosyal ilişkilerin uyum sürecini pozitif yönde yordayacağı değerlendirilmektedir.

Araștırmada spora yönelik tutum ile üniversite yaşamında sosyal uyum arasında pozitif yönlü ve düşük düzeyde bir ilişki tespit edilmiştir. Buna ek olarak; spora ilgi duyma, sporla yaşama ve aktif spor yaşamı ile üniversite yaşamına sosyal uyum arasında ise pozitif yönlü ve düşük düzeyde bir ilişkinin olduğu görülmektedir. Aynı zamanda spora yönelik tutumun üniversite yaşamında sosyal uyumu yordadığını gösteren mevcut araştırma bulgularına benzer olarak, üniversite öğrencilerinin sportif tutumlarının, yaşam kalitelerini açıklamada \%5,4 etki yarattığı saptanmıştır (Çoban, Bayazıt ve Uca, 2020). Bir diğer araştırmada öğrencilerin spora yönelik tutumları arttıkça okul iklimi algılarının da olumlu yönde arttığı görülmektedir (Kargın-Göktaş ve Şentürk, 2019). Dolayısıyla, spora yönelik tutumun artması farklı özellikleri de olumlu etkileyebilmektedir.

Üniversiteye uyum aşamasında temel sorunlar arasında sosyal problemler olduğunu belirten çalışmalar (Arici, 2019; Erdoğan, Şanlı ve Şimşek Bekir, 2005; Özkan ve Yılmaz, 2010; Sevinç ve Gizir, 2014), sosyal yetkinliğin üniversiteye olan uyumu olumlu yönde değiştirdiğinin altını çizmektedir (Sevinç-Tunahanioğlu ve Gizir, 2019). Üniversite yaşamına uyum sürecinde yaşanan sorunların önüne geçmede sosyal etkinliklerin önemi yadsınamaz bir katkı sağlamaktadır (İkiz ve Mete-Otlu, 2015). Sosyal ve sportif etkinlikler çerçevesinde öğrencilerin sosyalleşerek akran desteği ile karşılaşması muhtemeldir (Kiye, Yoncalık ve Nazlı, 2020; Özlük ve Karaaslan, 2017; Öztürk, 2020). Spor ortamlarında bulunmaları olası olan öğrenciler, sportif faaliyetler ile sosyal uyum düzeylerini de arttırabilmektedirler. Spor yalnızca bireylerin fiziksel ve psikolojik açıdan güçlenmesi için fayda sağlayan faaliyetler bütünü olmaktan çok daha ileri boyuta gitmiștir. Bunların yanı sıra spor, mesuliyet ve iş birliği ile bir düzen oluşturma yeteneğini ortaya çıkararak bireyin sosyalleşmesine katkı sağlayan önemli bir olgu olarak karşımıza çıkmaktadır (Küçük ve Koç, 2004). 
Dolayısıyla, üniversiteye uyumu etkileyen pek çok parametre olduğunu söylemek mümkündür (Akhan ve Arık Karamık, 2019; Akhunlar-Turgut, Sarıot-Ertürk, Karslı ve Şakiroğlu, 2020; Akyüz, Yılmaz, Aykul ve Pulat, 2019; İkiz, Asıcı, Savcı ve Yörük, 2015; Mert ve Çetiner, 2018; Sağınç, 2011; Yılmaz ve Zembat, 2019). Araştırma bulgularını destekleyen farklı bir araştırmada, üniversiteye uyum sağlama düzeyinde öğrencilerin spor yapıp yapmama durumlarına göre farklılık olup olmadığı incelenmiștir. Çalışmaya farklı fakültelerden katılan 1. sınıf öğrencileri ile yürütülen araştırma sonucuna göre, spor yapan öğrencilerin üniversiteye uyumlarında spor yapmayanlara göre daha çok zorlandıkları söylenebilir (Baba-Kaya ve Kaçay, 2017). Yükseköğrenim hayatına ve bu yeni hayatın beraberinde getirdiği değişkenlere uyum düzeyine olumlu katkı sunan bu parametreler (Bulut ve Bulut Serin, 2016), öğrencilerin yaşama ve topluma entegre olması adına önemli kaynaklar sunmaktadır.

Tüm bu bilgiler ışı̆̆ında sonuç olarak, spora yönelik tutumun üniversite yaşamında sosyal uyumu olumlu biçimde yordadığı belirlenmiştir. $\mathrm{Bu}$ noktadan hareketle; üniversitelerin bölüm farketmeksizin öğrenim göremekte olan öğrencilere yönelik sportif etkinliklerin planlanması ve teşvik edilmesi, üniversitede öğrenim görmekte olan öğrencilerin spor bilimleri fakültesi müfredatından yararlanabilmesinin önünün açılması ve çeşitli demografik değişkenlerinde çalışmaya katılarak araştırmanın derinleştirilmesi önerilmektedir.

\section{Yazışma Adresi (Corresponding Address):} Doç. Dr. Nuri Berk GÜNGÖR Karamanoğlu Mehmetbey Üniversitesi, Spor Bilimleri Fakültesi, KARAMAN ORCID: 0000-0002-6579-9146

E-posta: nuriberkgungor@gmail.com 


\section{Kaynaklar}

1. Akhan, N. E. ve Arık Karamık, G. (2019). Eğitim fakültesi birinci sınıf öğrencilerinin üniversiteye uyumlarının yaratıcı drama ile sağlanması. Eğitim Kuram ve Uygulama Araştırmaları Dergisi, 5(2), 141-152.

2. Akhunlar-Turgut, M. N., Sarıot-Ertürk, Ö., Karslı, F. ve Şakiroğlu, M. (2020). Algılanan stres ve üniversite yaşamına uyum iliş̧isinde bir aracı değişken: Ayrllık anksiyetesi. Hacettepe Üniversitesi Eğitim Fakültesi Dergisi, 35(2), 338-353.

3. Aktaş, Y. (1997). Üniversite öğrencilerinin uyum düzeylerinin incelenmesi: Uzunlamasına bir çalıșma. Hacettepe Üniversitesi Eğitim Fakültesi Dergisi, 13,117-110.

4. Akyüz, İ., Yılmaz, Ş., Aykul, M. ve Pulat, A. B. (2019). Gençlik ve Spor Bakanlığı'na bağlı yurtlarda kalan üniversite öğrencilerinin sosyal uyum düzeyleri. PESA Uluslararası Sosyal Araştırmalar Dergisi, 5(2), 92-106.

5. Arici, F. (2019). Üniversite öğrencilerinin üniversite eğitimi ve yaşamına ilişkin problemleri: Bir durum çalışması. İleri Eğitim Çalışmaları Dergisi, 1(2), 79-95.

6. Aslan, S. (2015). Üniversite yaşamına uyum ölçeğinin geliştirilmesi, Hacettepe Üniversitesi Eğitim Fakültesi Dergisi, 30(4), 132-145.

7. Atalı, L., Uzuner, M. E., Çolak, E. ve Bayazıt, B. (2018). Farklı fakültelerden spor ile ilgili ders alan öğrencilerin spora yönelik tutumlarının incelenmesi: Kocaeli Üniversitesi örneği. Journal of Social and Humanities Sciences Research (JSHSR), 5(30), 4428-4434.

8. Ayyldız-Durhan, T. (2020). The effect of leisure literacy on leisure exercise in university students. International Journal of Educational Methodology, 6(2), 381-391.

9. Ayyıldız-Durhan, T. A. ve Karaküçük, S. (2020). Ecorecreatıonal attitude of participants in sportive recreation activities. European Journal of Physical Education and Sport Science, 6(7), 61-81.

10. Baba-Kaya, H. ve Kaçay, Z. (2017). Üniversite öğrencilerinin spor yapma durumlarına göre üniversiteye uyum düzeylerinin incelenmesi. Journal of Human Sciences, 14(1), 738746.

11. Başkonuş, T. (2020). Ortaöğretim öğrencilerinin spora yönelik tutumlarının bazı değişkenlere göre incelenmesi: Kırșehir ili örneği. Ahi Evran Üniversitesi Sosyal Bilimler Enstitüsü Dergisi, 6(2), 365-376.

12. Belli, E., Bedir, F. ve Turan, M. (2019). Üniversite öğrencilerinin spora yönelik tutumları ile yaşam doyumları arasındaki ilişkinin incelenmesi, ETÜ Sosyal Bilimler Enstitüsü Dergisi, 9, 89-103.

13. Bindesen, Z. V. ve Bindesen, M. A. (2020). İnsan, spor ve felsefe (Spor felsefesine bir giriş). Beden Eğitimi ve Spor Bilimleri Dergisi, 22(4), 1-10.

14. Birsin-Yıldız, A., Arı, Ç. ve Yılmaz, B. (2017). Üniversite öğrencilerinin spora yönelik tutumlarının incelenmesi: Ankara Yıldırım Beyazıt Üniversitesi örneği. Muş Alparslan Üniversitesi Uluslararası Spor Bilimleri Dergisi, 1(1), 35-45.

15. Bulut, C. ve Bulut Serin, N. (2016). Öğretmen adaylarının üniversite yaşamına uyum düzeyleri ile yaşam doyumu arasındaki ilişkinin incelenmesi. International Journal of New Trends in Arts, Sports \&Science Education, 5(4), 1-7.

16. Caz, Ç., Bıçakçı, Y. S. ve Nakipoğlu-Firuzan, F. (2019). Spora yönelik tutum ile yaşam doyumu arasındaki ilişki: Marmara Üniversitesi Sosyal Bilimler Meslek Yüksekokulu öğrencileri örneği. Gümüşhane Üniversitesi Sosyal Bilimler Enstitüsü Elektronik Dergisi, 10(3), 484-491. 
17. Cengiz, R. ve Taşmektepligil, M. Y. (2016). Spor üzerine sosyolojik bir çözümleme: Spor merkezleri: Samsun örneği. Akademik Bakış Uluslararası Hakemli Sosyal Bilimler Dergisi, $56,220-240$.

18. Chan, K., Zhang, H. ve Wang, I. (2006). Materialism among adolescents in urban China. Young Consumers, 1, 64-76.

19. Çakır, F. ve Özdurak-Sıngın, R. H. (2019). Üniversite öğrencilerinde spora yönelik tutum ve internet bağımlılığı ilişkisin in incelenmesi. Sportif Bakış: Spor ve Eğitim Bilimleri Dergisi, 6(2), 163-178.

20. Çoban, Ü. (2019). Üniversite öğrencilerinin spora yönelik tutumlarının benlik saygısı, yaşam kalitesi, öz yeterlilik ve akademik başarı düzeylerine etkisinin incelenmesi: Doğu Marmara Bölgesi Üniversiteleri örneği (Doktora Tezi). Kocaeli Üniversitesi Sağlık Bilimleri Enstitüsü, Kocaeli.

21. Çoban, Ü., Bayazıt, B. ve Uca, M. (2020). Üniversite öğrencilerinin spora yönelik tutumlarının yaşam kalitesi düzeylerine etkisinin incelenmesi: Doğu Marmara Bölgesi üniversiteleri örneği. OPUS- Uluslararası Toplum Araştırmaları Dergisi, 15(26),4362-4385.

22. Çöllü, E. F. ve Öztürk, Y. E. (2006). Örgütlerde inançlar-tutumların ölçüm yöntemleri ve uygulama örnekleri bu yöntemlerin değerlendirilmesi. Sosyal Bilimler Meslek Yüksek Okulu Dergisi, 9(1-2), 375-376.

23. Demir, K. (2020). Bireylerin spora yönelik tutumları ile mutluluk düzeyleri arasındaki ilişkinin incelenmesi: Aydın Adnan Menderes Üniversitesi akademik personeli üzerine bir uygulama (Yüksek Lisans Tezi), Aydın Adnan Menderes Üniversitesi Sağlık Bilimleri Enstitüsü Beden Eğitimi ve Spor Eğitimi, Aydın.

24. Erdoğan, S., Şanlı, H. S. ve Şimșek-Bekir, H. (2005). Gazi Üniversitesi Eğitim Fakültesi öğrencilerinin üniversite yaşamına uyum durumları. Gazi Üniversitesi Kastamonu Eğitim Dergisi, 13(2), 479-496.

25. Esen-Aygün, H. ve Şahin Taşkın, Ç. (2019). Öğretmen adaylarının üniversite yaşamına sosyal, kişisel ve akademik uyumları. Trakya Eğitim Dergisi, 9(1), 12-31.

26. Gökdağ, M. (2018). Okul yöneticilerinin spora yönelik tutumları ve kadınların spor etkinliklerine katılımlarına dair görüşlerinin araștırılması: Bartın örneği (Yüksek Lisans Tezi). Bartın Üniversitesi Eğitim Bilimleri Enstitüsü, Bartın.

27. Göksel, A. G., Caz, Ç., Yazıcı, Ö. F. ve İkizler, H. C. (2017). Farklı bölümlerdeki öğrencilerin spora yönelik tutumlarının karşılaştırılması: Marmara Üniversitesi örneği. Spor ve Performans Araștırmaları Dergisi, 8(2), 123-134.

28. Güngör, N. B. ve Çelik, O. B. (2020). The effect of attitude towards sport of Sports Science Faculty students on mental well-being. International Journal of Eurasian Education and Culture, 5(8), 468-493.

29. Halıcı, A., Parasız, Ö. ve Yetim, A. A. (2020). Sayılarla Türkiye'de spor yöneticiliği eğitimi. Gazi Beden Eğitimi ve Spor Bilimleri Dergisi, 25(4), 299-312.

30. İkiz, E., Asıcı, E., Savcı, M. ve Yörük, C. (2015). Problemli internet kullanımı ile üniversite yaşamına uyum ilişkisi. Bartın Üniversitesi Eğitim Fakültesi Dergisi, 4(1), 34-50.

31. İkiz, F. E. ve Mete-Otlu, B. (2015). Üniversite yaşamına uyum sürecinde yaşanan sorunlar ve başa çıkma yolları. CBÜ Sosyal Bilimler Dergisi, 13(4), 35-52.

32. Kalfa, M. (2019). Diş Hekimliği Fakültesindeki öğrencilerinin spora yönelik tutumları. SPORMETRE Beden Eğitimi ve Spor Bilimleri Dergisi, 17(1), 165-181.

33. Karahan, T. F., Sardoğan, M. E., Özkamalı, E. ve Dicle, A. N. (2005a). Üniversite 1. sınıf öğrencilerinin üniversiteye uyum düzeylerinin sosyo-kültürel etkinlikler açısından incelenmesi. Çukurova Üniversitesi Eğitim Fakültesi Dergisi, 2(30), 63-72. 
34. Karahan, T. F., Sakdoğan, M., Özkamalı, E. ve Dicle, A. (2005b). Üniversite öğrencilerinin üniversite yaşamına uyum düzeylerinin denetim odağı ve atılganlık düzeyleri açısından incelenmesi. Dokuz Eylül Üniversitesi Buca Eğitim Fakültesi Dergisi, 18, 6-15.

35. Karasar, N. (2013). Bilimsel araștırma yöntemi (25. Basım). Ankara: Nobel.

36. Kargın-Göktaş, N. ve Şentürk, H. E. (2019). Spor lisesi öğrencilerinin okul iklimi algıları ile spora yönelik tutumları arasındaki ilişki. SPORMETRE Beden Eğitimi ve Spor Bilimleri Dergisi, 17(3), 78-92.

37. Kiye, S., Yoncalık, O. ve Nazlı, S. (2020). Lisans 1. sınıf öğrencilerinin üniversite yaşamına uyum sürecinde akran danıșmanlarının rolü. Kastamonu Education Journal, 28(6), 23462361.

38. Küçük, V. ve Koç, H. (2004). Psiko-sosyal gelişim süreci içerisinde insan ve spor ilişkisi. Dumlupınar Üniversitesi Sosyal Bilimler Dergisi, 9(1), 211-223.

39. Latchanna, G. ve Dagnew, A. (2009). Attitude of teachers towards the use of active learning methods. E-journal of All India Association for Educational Research, 21(1), 53-60.

40. Mert, A. ve Çetiner, P. (2018). Üniversite öğrencilerinin üniversite yaşamına uyum ile benlik ayrımlaşması arasındaki ilişkinin incelenmesi. Sakarya University Journal of Education, 8(3), 190-204.

41. Mızrak, O., Biricik, Y. S. ve Belli, E. (2017). Yetiştirme yurdunda kalan lise düzeyinde öğrencilerin spora yönelik tutumlarının incelenmesi. Atatürk Üniversitesi Beden Eğitimi ve Spor Bilimleri Dergisi, 19(2), 56-67.

42. Nacar, E., Gacar, A. ve Tutar, C.. F. (2019). Ortaöğretim öğrencilerinin spora karșı tutumlarının incelenmesi, Sosyal Bilimler Dergisi, 6(38), 73-85.

43. Napoli V., Kilbride, J. M., Tebs, D. E. (1996). Adjustment and growth in a changing world, New York: West.

44. Özkan, S. ve Yılmaz, E. (2010). Üniversite öğrencilerinin üniversite yaşamına uyum durumları: Bandırma örneği. Fırat Sağlık Hizmetleri Dergisi, 5(13), 153-171.

45. Özlük, B. ve Karaaslan, A. (2017). Sağlık Bilimleri Fakültesi birinci sınıf öğrencilerinin üniversite yaşamına uyumunda akran desteğinin etkisi. Uluslararası Eğitim Bilimleri Dergisi, 4(10), 209-222.

46. Öztürk, N. (2020). Eğitim Fakültesi birinci sınıf öğrencilerinin üniversite yașamına uyumları: Akran desteğinin yordayıcı rolü. Anemon Muş Alparslan Üniversitesi Sosyal Bilimler Dergisi, 8(1), 63-72.

47. Sağınç, N. (2011). Üniversite yaşamına uyum sürecine etki eden faktörler ve birbirleri ile ilişkileri (Yüksek Lisans Tezi). Uludağ Üniversitesi Sağllk Bilimleri Enstitüsü, Bursa.

48. Sarı, A. ve Taylan, S. (2020). İlk ve acil yardım önlisans programı öğrenci ve mezunlarının spora yönelik tutumlarının değerlendirilmesi. SPORMETRE Beden Eğitimi ve Spor Bilimleri Dergisi, 18(2), 39-49.

49. Sevinç-Tuhanioğlu, S. ve Gizir, C. A. (2019). Üniversite birinci sınıf öğrencilerinin üniversite yaşamına uyumlarına katkı sağlayan bireysel ve çevresel faktörlerin incelenmesi. Yükseköğretim Dergisi, 9(3), 249-262.

50. Sevinç, S. ve Gizir, C.A. (2014). Üniversite birinci sınıf öğrencilerinin bakış açılarından üniversiteye uyumu olumsuz etkileyen faktörler: Mersin Üniversitesi örneği. Kuram ve Uygulamada Eğitim Bilimleri, 14(4), 1-24.

51. Şentürk, H. E. (2012). Sportif tutum ölçeği: geliştirilmesi, geçerliliği ve güvenirliği. $C B U ̈$ Beden Eğitimi ve Spor Bilimleri Dergisi, 7(2), 8-18.

52. Şimşek, A. ve Karahüseyinoğlu, M. F. (2020). Üniversite öğrencilerinin spora yönelik tutumlarının incelenmesi: Fırat Üniversitesi örneği. Spor ve Performans Araştırmaları Dergisi, 11(1), 46-54. 
53. Tabachnick, B. G. ve Fidell, L. S. (2013). Using multivariate statistics. Boston:Pearson.

54. Tukel, Y. (2018). Rekreatif amaçlı spor yapanların spora yönelik tutumlarının cinsiyete ve medeni duruma göre değerlendirilmesi. Spor, Eğitim ve Rekreasyon Dergisi (SPORTIVE), 1(1), 12-18.

55. Türkmen, M, Abdurahimoğlu, Y., Varol, S. ve Gökdağ, M. (2016). İslami İlimler Fakültesi öğrencilerinin spora yönelik tutumlarının incelenmesi: Bartin Üniversitesi örneği. International Journal of Contemporary Educational Studies (IntJCES), 2(1), 48-59.

56. Varol, R. (2017). Üniversite öğrencilerinin spora yönelik tutumları ve kadınların spor etkinliklerine katılımlarına dair görüşlerinin incelenmesi: Bartın Üniversitesi örneği (Yüksek Lisans Tezi). Bartın Üniversitesi Eğitim Bilimleri Enstitüsü, Bartın.

57. Varol, R., Varol, S. ve Türkmen, M. (2017). Bartın Üniversitesinde öğrenim gören öğrencilerin spora yönelik tutumlarının belirlenmesi. International Journal of Cultural and Social Studies (IntJCSS), 3(2), 316-329.

58. Yanık, M. ve Çamlıyer, H. (2015). Ortaöğretim 9. sınıf öğrencilerinin beden eğitimi ve spora ilişkin tutumları ile okula yabancılaşma düzeyleri arasındaki ilişkinin belirlenmesi. Uluslararası Spor, Egzersiz ve Antrenman Bilimi Dergisi, 1, 9-19.

59. Yarayan, Y. E., Yıldız, A. B., ve Gülşen, D. B. A. (2018). Elit düzeyde bireysel ve takım sporu yapan sporcuların zihinsel dayanıklılı düzeylerinin çeşitli değişkenlere göre incelenmesi. Uluslararası Sosyal Araştırmalar Dergisi, 11(57), 992-999.

60. Yarayan, Y. E., Yıldız, A. B., Gülşen, D. B. A. ve İlhan, L. (2020). Futbolculuk seviyesi prososyal ve antisosyal davranışların bir belirleyicisi midir? Spormetre Beden Eğitimi ve Spor Bilimleri Dergisi, 18(4), 125-133.

61. Yavuz, C. ve Yücel, A. S. (2019). Spor Yöneticiliği Bölümü öğrencilerinin spora yönelik tutumlarının bazı değişkenlere göre incelenmesi. Elektronik Sosyal Bilimler Dergisi, 18(72), 1902-1910.

62. Yetim, A. (2000). Sporun sosyal görünümü. Gazi Beden Eğitimi ve Spor Bilimleri Dergisi, 5(1), 63-72.

63. Yıldırım, M., Araç-Ilgar, E. ve Uslu, S. (2018). Lise öğrencilerinin spora yönelik tutumlarının incelenmesi. Turkish Studies Educational Sciences. 13(27), 1711-1727.

64. Yılmaz, H. ve Zembat, R. (2019). Okul öncesi öğretmen adaylarının duygusal zekâ düzeyleri ile üniversite yaşamına uyumları arasındaki ilişkinin incelenmesi. Mehmet Akif Ersoy Üniversitesi Eğitim Fakültesi Dergisi, 52, 118-136.

65. Zaman, S., Mian, A. K. ve Butt, F. (2018). Attitude of young students towards sports and physical activities. GMJACS, 8(1), 33-40. 